Watkins, J. F. (1960). J. gen. Microbiol. 22, 57-71

\title{
The Early Stages of Infection of HeLa Cells with Herpes Simplex Virus
}

\author{
By J. F. WATKINS* \\ Department of Bacteriology, University of Manchester
}

\begin{abstract}
SUMMARY : Evidence is presented which suggests that after a period of adsorption of $\mathbf{3 0} \mathrm{min}$. the herpes virus which could not be removed from HeLa cells by repeated washing existed in four fractions: Fraction $A$, about $63 \%$, which became non-infective and insusceptible to antiserum over the next $2 \mathrm{hr}$.; fraction $\mathrm{B}$, about $16 \%$, which remained susceptible to antiserum and infective for up to $6 \mathrm{hr}$. after adsorption; fraction $\mathbf{C}$, about $2 \%$, which remained infective and insusceptible to antiserum for at least $6 \mathrm{hr}$. after adsorption; fraction $\mathrm{D}$, about $19 \%$, which became non-infective and insusceptible to antiserum during the adsorption period. Replication occurred from fractions $A$ and $D$. Inactivation and the development of insusceptibility to antiserum occurred very close together in time, possibly simultaneously. Incubation of infected cells in the presence of antiserum lowered the yield of virus obtained after $48 \mathrm{hr}$. incubation; this could not be explained simply by prevention of secondary infection through the medium.
\end{abstract}

In the preceding paper (Watkins, 1960) the kinetics of herpes virus infection of chorio-allantoic membrane (CAM) ectodermal cells was discussed, and a picture of the sequence of events following adsorption was proposed. In order to find evidence to corroborate the conclusions reached from CAM experiments, the behaviour of the virus was studied in HeLa cells, since these provided a more homogeneous system. Also, since HeLa cells can be disintegrated very thoroughly by ultrasonic oscillations, it was hoped to overcome the problem of assessing the efficiency of extraction of adsorbed virus which made interpretation of CAM experiments difficult.

\section{METHODS}

Virus, immune serum and diluting and washing fluids. These were described in the preceding paper (Watkins, 1960).

HeLa cells. These were propagated in $500 \mathrm{ml}$. flat screw-capped bottles in a medium consisting of $10 \%(\mathrm{v} / \mathrm{v})$ lactalbumin hydrolysate in Hanks's balanced saline solution. Sodium bicarbonate solution $(0.02 \mathrm{ml}$. of $1.4 \%$, $\mathrm{w} / \mathrm{v}$, solution) and 100 units of penicillin and streptomycin were added per ml. medium. For use in experiments monolayers of HeLa cells were grown in $25 \mathrm{ml}$. screw-capped bottles in the same medium. Some of the earlier experiments were carried out with monolayers in Petri dishes of $50 \mathrm{~mm}$. diam. incubated in an atmosphere of $5 \%(\mathrm{v} / \mathrm{v}) \mathrm{CO}_{2}$ in air. After infection of the cells, these were incubated and a medium consisting of $10 \%(\mathrm{v} / \mathrm{v})$ calf serum and $0.02 \%$ lactalbumin hydrolysate in Hanks's saline with sodium

\footnotetext{
- Present address: Sir William Dunn School of Pathology, Oxford.
} 
bicarbonate and antibiotics was added as before. Cells were removed from the glass by replacing the medium with $0.02 \%$ ethylenediaminetetra acetic acid (EDTA) in phosphate buffered saline ( $\mathrm{pH} \mathrm{7 \cdot 2)}$ and were incubated for 15-20 min. at $87^{\circ}$.

Infection of cells. Two $\mathrm{ml}$. of stock virus suspension diluted to the desired strength in $5 \%(\mathrm{v} / \mathrm{v})$ horse serum in Hanks's solution $(5 \% \mathrm{HSH})$ were used as the inoculum in all experiments, unless otherwise stated.

Disintegration of cells. Infected HeLa cells were removed from $25 \mathrm{ml}$. bottles with $2 \mathrm{ml}$. EDTA solution. The effect of EDTA on the virus was determined by titrating in parallel dilutions of virus in EDTA and $5 \%$ HSH. The dilution tube of the EDTA series from which samples had been taken for titration was incubated for $60 \mathrm{~min}$. at $37^{\circ}$ and then re-titrated. Table 1 shows that there was no significant difference between the counts.

Table 1. Effect of EDTA on infectivity of herpes virus

$\begin{array}{cc} & \text { IU/ml. } \\ \text { Titre of virus diluted in } 5 \% \text { HSH } & 1.6 \times 10^{7} \\ \text { Titre of virus diluted in } 0.02 \% \text { EDTA } & 1.4 \times 10^{7} \\ \text { Titre of virus diluted in } 0.02 \% \text { EDTA } & 1.5 \times 10^{7} \\ \text { and placed at } 37^{\circ} \text { for } 60 \mathrm{~min} . & \end{array}$

Table 2. Nuclear counts on HeLa cells disintegrated by ultrasonic oscillations

\begin{tabular}{|c|c|c|c|}
\hline Medium & $\begin{array}{c}\text { Nuclei/dish } \\
\text { at } 0 \text { sec. }\end{array}$ & $\begin{array}{l}\text { Nuclei/dish } \\
\text { at } 60 \text { sec. }\end{array}$ & $\begin{array}{c}\% \\
\text { disintegration }\end{array}$ \\
\hline $\begin{array}{l}\text { Distilled water } \\
\text { Hanks's saline } \\
10 \% \text { Horse-serum Hanks's } \\
\text { saline }\end{array}$ & $\begin{array}{l}8.0 \times 10^{6} \\
3.6 \times 10^{6} \\
4.1 \times 10^{6}\end{array}$ & $\begin{array}{l}1.8 \times 10^{4} \\
4.0 \times 10^{4} \\
6.0 \times 10^{4}\end{array}$ & $\begin{array}{l}99 \cdot 4 \\
99 \cdot 0 \\
98 \cdot 5\end{array}$ \\
\hline HeLa cell growth medium & $8.8 \times 10^{6}$ & $2.0 \times 10^{4}$ & $99 \cdot 5$ \\
\hline
\end{tabular}

The HeLa cells suspended in $2 \mathrm{ml}$. EDTA solution were placed in a $50 \mathrm{~mm}$. diam. Petri dish and disintegrated by $1 \mathrm{~min}$. treatment with a Mullard $50 \mathrm{~W}$. ultrasonic drill, using a 1:1 ratio chromium-plated stub vibrating at 20,000 cyc./sec. Nuclear counts showed this method of disintegration to be very effective (Table 2). The nuclei remaining after $1 \mathrm{~min}$. disintegration were severely damaged and stripped of cytoplasm. Counts were not performed on cells disintegrated in EDTA solution, but examination of wet films showed a decrease of the same order in the number of nuclei.

The disintegrated material from a single monolayer was either titrated at once or mixed with an equal volume of skimmed milk and held at $-20^{\circ}$ after rapid freezing to await titration not more than 1 week later. Storage of virus under these conditions caused very little decrease in titre, even after storage for 3 months. Ultrasonic treatment under these conditions had no effect on the virus, as shown by the following experiment.

Stock virus was diluted so that $2 \mathrm{ml}$. contained about $4.0 \times 10^{2} \mathrm{IU}$. This volume of virus suspension was placed in a $50 \mathrm{~mm}$. Petri dish and subjected to ultrasonic treatment for 2 min. The suspension was titrated on 
4. CAM's by sampling directly from the dish without further dilution, before and after ultrasonic treatment. Before treatment the suspension contained $170 \mathrm{IU} / \mathrm{ml}$., and after treatment $210 \mathrm{IU} / \mathrm{ml}$; t this difference is not significant. Repetition of the experiment in $0.02 \%(w / v)$ EDTA solution gave a similar result.

Titration of virus. Infectivity was titrated on 13-day CAM's as described in the preceding paper.

\section{RESULTS \\ Adsorption}

Attempts were made at first to measure the amount of virus adsorbed to monolayers in $\mathbf{5 0 ~} \mathrm{mm}$. Petri dishes by titrating the virus lost from an inoculum of $4 \mathrm{ml}$. at intervals after addition. In these experiments the inoculum consisted of stock virus diluted $1 / 10$ in Hanks's saline, giving a virus suspension in $5 \%(v / v)$ skimmed milk. Virus was found to be as stable in this mixture as in $5 \% \mathrm{HSH}$. Table 3 shows that there was no significant decrease in the titre of the inoculum.

Table 3. Titration of inoculum in contact with HeLa cells for varying periods

\begin{tabular}{|c|c|c|}
\hline & $\begin{array}{c}\text { Expt. 39 } \\
\text { titrations on } \\
5 \text { CAM's/dilution } \\
\text { IU/dish }\end{array}$ & $\begin{array}{c}\text { Expt. 42 } \\
\text { titrations on } \\
10 \text { CAM's/dilution } \\
\text { inoculum }\end{array}$ \\
\hline contact (min.) & $\begin{array}{l}\text { IU/dish in inoculum } \\
\text { T }\end{array}$ & \\
\hline $\begin{array}{l}\mathbf{0} \\
\mathbf{5}\end{array}$ & $1.4 \times 10^{4}$ & $\begin{array}{l}3.6 \times 10^{8} \\
5.5 \times 10^{8}\end{array}$ \\
\hline 10 & - & $8.5 \times 10^{3}$ \\
\hline 15 & - & $4.0 \times 10^{3}$ \\
\hline $\mathbf{3 0}$ & $1.5 \times 10^{4}$ & - \\
\hline 60 & $1.2 \times 10^{4}$ & - \\
\hline
\end{tabular}

The failure to find a significant decrease in the titre of the inoculum in these experiments was perhaps not surprising in view of the much greater depth of the inoculum here (about $2 \mathrm{~mm}$.) than on the CAM in the experiments in the preceding paper (Watkins, 1960), where it was of the order of $0.2 \mathrm{~mm}$. Since most of the experiments on adsorption described here were done before the experiments on CAM had indicated that virus might be very rapidly inactivated upon adsorption, it seemed reasonable to study only the virus which could be recovered from monolayers by ultrasonic treatment after adsorption and vigorous washing. In the present paper 'adsorbed virus' refers throughout to virus recovered in this way. Any virus which may have been adsorbed and have become rapidly inactivated, as seems to happen in CAM cells, does not enter directly into the experiments. There is some reason for thinking, as will be shown later, that virus recovered from HeLa cells in fact represents the greater part of the virus which has adsorbed, so that the fate of virus attached to HeLa cells may differ from its fate in CAM ectoderm.

The experiments on recovery of virus after different adsorption periods 
(Table 4) were carried out in monolayers on $50 \mathrm{~mm}$. Petri dishes with stock virus diluted $1 / 10$ in Hanks's saline (giving a final dilution of skimmed milk of $1 / 20$ ), or in $5 \%$ HSH. Subsequent measurements of the same nature, made after infection of monolayers in $25 \mathrm{ml}$. flat bottles, with $2 \mathrm{ml}$. inocula, gave substantially the same results. Adsorption was carried out at $37^{\circ}$. Before titration the inoculum was pipetted off and the monolayers were washed three times with $5 \mathrm{ml} .5 \% \mathrm{HSH}$. Two $\mathrm{ml} .5 \% \mathrm{HSH}$ were then placed in the dishes and the cells were disintegrated as described. The amounts recovered after adsorption for $60 \mathrm{~min}$. were $3 \cdot 3-6.7 \%$ of the inoculum, mean value of $4.8 \%$. The proportion recovered increased with time. Table 5 shows that the amount of adsorbed virus recovered in this way was not changed by repeated washing. Four monolayers received the same inoculum, which was allowed to adsorb for $80 \mathrm{~min}$. at $37^{\circ}$. Individual monolayers were then washed, respectively, 2, 6, 8 or 10 times with $5 \mathrm{ml} .5 \% \mathrm{HSH}$, disintegrated and titrated on 3 CAM's/ monolayer. Even after 10 washings there was no significant decrease in the amount of recovered virus.

Table 4. Adsorption of herpes simplex virus to HeLa cell monolayers at $\mathbf{3 7}^{\circ}$

\begin{tabular}{|c|c|c|c|c|c|c|}
\hline \multirow{2}{*}{ Expt. } & \multirow{2}{*}{$\begin{array}{l}\text { Inoculum } \\
\text { (no. of IU) }\end{array}$} & \multicolumn{5}{|c|}{ Period of adsorption } \\
\hline & & 10 sec. & 5 min. & $\begin{array}{l}15 \text { min. } \\
\% \text { adsorbed }\end{array}$ & 30 min. & $60 \mathrm{~min}$. \\
\hline 48 & $8.0 \times 10^{5}$ & - & $2 \cdot 1$ & $\mathbf{2 \cdot 5}$ & - & $\mathbf{3 \cdot 3}$ \\
\hline 45 & $4.7 \times 10^{6}$ & - & 1.1 & - & 2.1 & $5 \cdot 3$ \\
\hline 48 & $2.7 \times 10^{5}$ & - & 2.1 & $\mathbf{2 \cdot 9}$ & $5 \cdot 7$ & 6.7 \\
\hline 54 & $3.4 \times 10^{8}$ & $0 \cdot 17$ & - & - & - & - \\
\hline 56 & $4.0 \times 10^{4}$ & 0.2 & 3.4 & - & - & 4.0 \\
\hline & Means & 0.10 & $2 \cdot 2$ & $2 \cdot 7$ & $\mathbf{3 \cdot 9}$ & 4.82 \\
\hline
\end{tabular}

Table 5. Resistance of virus adsorbed to HeLa cells to vigorous washing

$\begin{array}{cc}\begin{array}{c}\text { Inoculum: } 2.0 \times 10^{6} \mathrm{IU} / \text { monolayer } \\ \text { Number of } \\ \text { washes }\end{array} & \begin{array}{c}\text { IU recovered/ } \\ \text { monolayer }\end{array} \\ 2 & 2.8 \times 10^{4} \\ 6 & 4.4 \times 10^{4} \\ 8 & 2.5 \times 10^{4} \\ 10 & 4.0 \times 10^{4}\end{array}$

To estimate the variation in recoverable virus, 5 monolayers were exposed to the same inoculum of virus in Petri dishes under exactly the same conditions. After adsorption for $\mathbf{3 0} \mathrm{min}$. the monolayers were washed three times and recoverable virus titrated in the standard manner on $8 \mathrm{CAM}$ 's/dish. The mean amount recovered/dish was $4240 \mathrm{IU}$; the standard error of the mean was 240. The $95 \%$ fiducial limits on 4 degrees of freedom $(t=2 \cdot 78)$ were 3600 $4880(=$ mean $\pm 15 \%)$. As a simple working rule, therefore, the virus recovered from two similar dishes which had been infected and assayed in the same way would be most unlikely to differ by chance by more than $\mathbf{3 0} \%$. 
All the studies of herpes virus infection described in this paper were made on the firmly bound virus which could be released by ultrasonic treatment. In the experiments on the CAM (Watkins 1960), where virus recovery was attempted by freezing and grinding, only c. $0 \cdot 1 \%$ of the inoculum was recovered from washed CAM's at the end of an adsorption period of $60 \mathrm{~min}$.; 3.3-6.7 \% of the inoculum, however, was recovered from HeLa cells after the same period. In other words, $80-60$ times more of the inoculum was recovered from HeLa cells than from CAM. The question arises whether this was due to a more efficient method of recovery from HeLa cells than from CAM, or to a difference in the behaviour of virus adsorbed to the two kinds of cell. Evidence has been given in the preceding paper (Watkins, 1960) that the low recovery from CAM's was due to inactivation of virus. Other considerations, which follow, suggest that the situation is different in the two types of cell.

(a) Ultrasonic treatment of infected CAM failed to increase the amount of virus recovered.

(b) The greater depth of inoculum on HeLa cells would cause less virus to be adsorbed to them than to CAM ectoderm in a similar period. Furthermore, no significant decrease in the inoculum comparable to that found in CAM was found in HeLa cells, which suggests that in any case not more than $30 \%$ of the inoculum could have adsórbed.

(c) Virus recovered from HeLa cells increased during the adsorption period while, in an analogous experiment in CAM, recoverable virus showed a slight decrease.

(d) Virus recovered from CAM's at intervals after adsorption showed little tendency to decrease in amount, while that recovered from HeLa cells, as shown later, decreased by up to $90 \%$ in $2 \mathrm{hr}$.

(e) In Table 9 (discussed in detail later) it will be seen that the ratio of virus recovered after $48 \mathrm{hr}$. incubation at $37^{\circ}$ of infected washed HeLa cells to the amount recovered from similar monolayers at the end of adsorption has a mean value of $21 \cdot 7$; this is of the same order as the value found by Wildy, Stoker \& Ross (1959) for the amount of virus released after incubation for $33 \mathrm{hr}$. by a single infected HeLa cell. This supports the assumption that most of the adsorbed infective virus gave rise to new virus.

On balance it seems safe to assume that infective virus recovered from HeLa cells after adsorption represents most of the virus which has been adsorbed. The interpretation that inactivation of virus adsorbed to HeLa cells was slower than that of virus adsorbed to CAM depends, therefore, on the correctness of the conclusions reached in the preceding paper (Watkins, 1960).

\section{Effect of HeLa cell disintegrate on infectivity}

To determine whether the products of ultrasonic disintegration of HeLa cells would inactivate virus the following experiment was performed. HeLa cells $\left(1.5 \times 10^{7}\right)$ were washed once in Hanks's saline and suspended in $5 \mathrm{ml}$. of $1 / 200$ dilution of skimmed milk in Hanks's saline (in which virus was known to be quite stable for $1 \mathrm{hr}$. at $87^{\circ}$ ). The HeLa cells were disintegrated and the 
suspension centrifuged at $400 \mathrm{~g}$ for $10 \mathrm{~min}$. to remove any cells which might not have been disintegrated; there was then no deposit visible to the naked eye. Stock virus was diluted to $10^{-5}$ in the supernatant fluid and also in $1 / 200$ dilution skimmed milk in Hanks's saline. The latter suspension was titrated at once; both suspensions were titrated again after standing at $37^{\circ}$ for $30 \mathrm{~min}$. As in the CAM, disintegrated cell material did not decrease the infectivity of herpes virus.

\section{Inactivation of bound virus}

After infection of monolayers of HeLa cells by a $30 \mathrm{~min}$. adsorption period as described, the monolayers were washed three times and then covered with $4 \mathrm{ml}$. fresh medium. The virus content of the monolayers was assayed after different intervals of incubation at $37^{\circ}$. In five experiments (Table 6) a considerable decrease in the amount of recoverable virus was observed, in that

Table 6. Inactivation of virus bound to HeLa cell monolayers

\begin{tabular}{|c|c|c|c|c|c|c|c|}
\hline \multirow{3}{*}{$\begin{array}{l}\text { Time after } \\
\text { end of } \\
\text { adsorption } \\
\text { period } \\
\text { (30 min.) } \\
\text { at which virus } \\
\text { was recovered } \\
\text { o min. }\end{array}$} & \multicolumn{5}{|c|}{ Experiment } & \multirow{2}{*}{\multicolumn{2}{|c|}{$\begin{array}{l}\text { Control } \\
\text { (3 CAM's/ } \\
\text { dilution) } \\
\text { (IU/0.3 ml./ }\end{array}$}} \\
\hline & \multicolumn{5}{|c|}{ 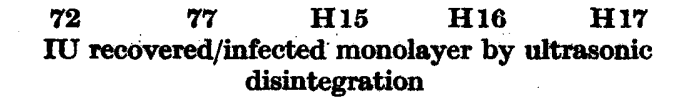 } & & \\
\hline & $\begin{array}{c}8.0 \times 10^{5} \\
100 \%\end{array}$ & $\begin{array}{c}1.9 \times 10^{5} \\
100 \%\end{array}$ & $\begin{array}{c}2.9 \times 10^{4} \\
100 \%\end{array}$ & $\begin{array}{c}2.0 \times 10^{5} \\
100 \%\end{array}$ & $\begin{array}{c}4.2 \times 10^{4} \\
100 \%\end{array}$ & $100 \%$ & $\begin{array}{l}5.4 \times 10^{4} \\
100 \%\end{array}$ \\
\hline 60 min. & 一 & - & - & $\begin{array}{c}1.2 \times 10^{5} \\
60 \%\end{array}$ & - & $\overline{60} \%$ & - \\
\hline 2 hr. & $\begin{array}{r}3.4 \times 10 \\
11.1 \%\end{array}$ & $\begin{array}{r}2.3 \times 10^{4} \\
12.0 \%\end{array}$ & $\begin{array}{r}1.8 \times 10^{8} \\
6.2 \%\end{array}$ & $\begin{array}{c}4.8 \times 10^{4} \\
24 \%\end{array}$ & $\begin{array}{c}2.0 \times 10^{4} \\
48 \%\end{array}$ & $\overline{20.2} \%$ & $\begin{array}{c}5 \cdot 1 \times 10^{4} \\
95 \%\end{array}$ \\
\hline $4 \mathrm{hr}$. & - & $\begin{array}{r}1.6 \times 10^{4} \\
8.6 \%\end{array}$ & $\begin{array}{r}1.9 \times 10^{3} \\
6.1 \%\end{array}$ & $\begin{array}{c}6.0 \times 10 \\
30 \%\end{array}$ & $\begin{array}{r}7.0 \times 10^{2} \\
16.8 \%\end{array}$ & $\overline{15.8} \%$ & $\begin{array}{c}3.6 \times 10^{4} \\
67 \%\end{array}$ \\
\hline $6 \mathrm{hr}$. & - & $\begin{array}{r}2.2 \times 10^{4} \\
11.5 \%\end{array}$ & $\begin{array}{r}1.5 \times 10^{3} \\
5.2 \%\end{array}$ & - & $\begin{array}{r}4.0 \times 10^{8} \\
9.5 \%\end{array}$ & $\overline{8.7} \%$ & $\begin{array}{c}2.2 \times 10^{4} \\
41 \%\end{array}$ \\
\hline $8 \mathrm{hr}$. & - & $\div$ & 一 & - & - & - & $\begin{array}{c}8.0 \times 10^{4} \\
56 \%\end{array}$ \\
\hline
\end{tabular}

from 6.2 to $48 \%$ (mean value $20 \cdot 2 \%$ ) of bound virus infectivity was recovered $2 \mathrm{hr}$. after adsorption. In a control experiment $7 \cdot 2 \times 10^{5} \mathrm{IU}$ in $4 \mathrm{ml}$. medium were incubated at $37^{\circ}$ for $8 \mathrm{hr}$. and $0.3 \mathrm{ml}$. samples were removed every $2 \mathrm{hr}$., diluted, and titrated on 3 CAM's. The $44 \%$ decrease after $8 \mathrm{hr}$. is of doubtful significance, because of the small number of eggs used in the titration; in any case it was much less than the decrease in virus attached to cells. In two of the experiments which continued for $6 \mathrm{hr}$. there was no further decrease after $2 \mathrm{hr}$.; in another the decrease at $2 \mathrm{hr}$. was less marked, but virus continued to decrease in titre over the next $4 \mathrm{hr}$.

\section{Effect of immune serum on bound virus}

HeLa cells were infected, as described, with an adsorption period of $60 \mathrm{~min}$. After the monolayers had been washed three times with $5 \mathrm{ml} .5 \% \mathrm{HSH}$, $5 \mathrm{ml}$. medium were added, and then $0.2 \mathrm{ml}$. hyperimmune rabbit herpes anti- 
serum was added to the medium at intervals after adsorption. The antiserum was allowed to act for $15 \mathrm{~min}$.; then the monolayers were washed three times and assayed for recoverable virus. Control experiments provided no evidence that antibody was adsorbed to HeLa cell monolayers in such a way that it might be released by ultrasonic treatment and so neutralize the recovered virus. In another control experiment normal serum from two rabbits and serum from a rabbit which had been immunized by 5 weekly intravenous injections of $10^{6}$ live HeLa cells, had no effect on bound virus.

Table 7. Virus recovered from infected monolayers when antiserum was added at intervals after 30 min. adsorption

\begin{tabular}{|c|c|c|c|c|c|c|c|}
\hline \multirow{3}{*}{$\begin{array}{l}\text { Time after } \\
\text { end of } \\
\text { adsorption } \\
\text { period at } \\
\text { which } \\
\text { antiserum } \\
\text { added } \\
\text { No antiserum }\end{array}$} & \multicolumn{6}{|c|}{ Experiment } & \multirow{2}{*}{$\begin{array}{c}\text { Mean } \\
(\%)\end{array}$} \\
\hline & 71 & 73 & $\begin{array}{c}78 \\
\text { U recovered }\end{array}$ & $\begin{array}{c}\text { H15 } \\
\text { //monolaye }\end{array}$ & er $\mathbf{H 1 6}$ & H17 & \\
\hline & $\begin{array}{c}1.9 \times 10^{5} \\
100 \%\end{array}$ & $\begin{array}{c}3.5 \times 10^{5} \\
100 \%\end{array}$ & $\begin{array}{c}1.9 \times 10^{5} \\
100 \%\end{array}$ & $\begin{array}{c}2.9 \times 10^{4} \\
100 \%\end{array}$ & $\begin{array}{c}2.0 \times 10^{5} \\
100 \%\end{array}$ & $\begin{array}{c}4.2 \times 10^{4} \\
100 \%\end{array}$ & $100 \%$ \\
\hline 0 min. & $\begin{array}{r}8.8 \times 10^{2} \\
0.46 \%\end{array}$ & $\begin{array}{r}1.7 \times 10^{3} \\
0.5 \%\end{array}$ & $\begin{array}{r}5 \cdot 4 \times 10^{3} \\
2.8 \%\end{array}$ & $\begin{array}{r}1.2 \times 10^{3} \\
4.1 \%\end{array}$ & $\begin{array}{c}3.8 \times 10^{4} \\
(19 \%)\end{array}$ & $\begin{array}{r}1.7 \times 10^{3} \\
4.0 \%\end{array}$ & $2 \cdot 4$ \\
\hline $30 \mathrm{~min}$. & $\begin{array}{r}4.0 \times 10^{2} \\
0.21 \%\end{array}$ & - & - & - & - & - & $(0 \cdot 2)$ \\
\hline $1 \mathrm{hr}$. & $\begin{array}{r}1.0 \times 10^{2} \\
0.05 \%\end{array}$ & $\begin{array}{r}1.4 \times 10^{8} \\
0.4 \%\end{array}$ & - & - & - & - & $(0 \cdot 2)$ \\
\hline $2 \mathrm{hr}$. & $\begin{array}{r}8.0 \times 10^{2} \\
0.42 \%\end{array}$ & $\begin{array}{r}\mathbf{8 . 2} \times 10^{3} \\
0.9 \%\end{array}$ & $\begin{array}{r}9.6 \times 10^{2} \\
0.5 \%\end{array}$ & $\begin{array}{r}4.0 \times 10^{2} \\
1.4 \%\end{array}$ & $\begin{array}{r}1.1 \times 10^{8} \\
0.55 \%\end{array}$ & $\begin{array}{r}2.1 \times 10^{8} \\
\quad 5.0 \%\end{array}$ & 1.5 \\
\hline $4 \mathrm{hr}$. & - & - & $\begin{array}{r}1.2 \times 10^{8} \\
0.63 \%\end{array}$ & $\begin{array}{r}4.1 \times 10^{2} \\
1.4 \%\end{array}$ & $\begin{array}{r}3.7 \times 10^{3} \\
1.4 \%\end{array}$ & $\begin{array}{r}1.3 \times 10^{8} \\
3.1 \%\end{array}$ & 0.0 \\
\hline $6 \mathrm{hr}$. & - & - & $\begin{array}{c}2.0 \times 10^{2} \\
0.13 \%\end{array}$ & $\begin{array}{r}5.2 \times 10^{2} \\
1.8 \%\end{array}$ & - & $\begin{array}{r}1.2 \times 10^{3} \\
2.9 \%\end{array}$ & $1 \cdot 6$ \\
\hline
\end{tabular}

Table 7 shows that in five out of six experiments between 0.46 and $4.1 \%$ of bound virus was insusceptible to antiserum at the end of the adsorption period (mean value of $2.4 \%$ ). The 0 min. figure of $19 \%$ in experiment $\mathrm{H} 16 \mathrm{did}$ not agree with the values from the other 5 experiments; since there were other reasons for suspecting it, this value was not included in calculating the mean. Between 2 and $6 \mathrm{hr}$. after adsorption the amount of insusceptible virus altered very little, perhaps showing a slight decrease. In CAM's (Watkins, 1960) 30-60\% of bound virus had become insusceptible at the end of the adsorption period. Stoker \& Ross (1958) also found that a small proportion of herpes virus adsorbed to HeLa cells was insusceptible to antiserum and remained fairly constant in amount throughout the latent period. It seemed possible that this finding of apparently insusceptible virus might be due to dissociation of antibody-virus complexes on washing; therefore the following experiment was carried out. Four monolayers which had been infected with inocula of the same size and treated with $0.1 \mathrm{ml}$. antiserum in $5 \mathrm{ml}$. medium for $15 \mathrm{~min}$. were 
washed respectively $2,4,8$ and 10 times with $5 \% \mathrm{HSH}$; recoverable virus was then determined. Repeated washing did not increase virus recovery, so that a constant amount of virus-antibody complex is not dissociated at each wash. The decrease of $c .50 \%$ after 10 washes in this one experiment may indicate that the insusceptible virus was less firmly attached than was the susceptible virus (compare Table 5); this point was not further investigated. The small amount of 'insusceptible' virus may represent a small proportion of attached virus which combines very feebly with antibody, so that the union is broken once and for all by one or two washes, but since it remained fairly constant (Table 8) while $80 \%$ of the total bound virus was inactivated this explanation seems unlikely.

Table 8. Effect of repeated washing of infected monolayers 16 min. after the addition of antiserum

About 5.0 $\times 10^{4} \mathrm{IU}$ adsorbed during $30 \mathrm{~min}$. at $37^{\circ}$

Virus recovered from monolayer washed $\left\{\begin{array}{rc}2 & 1 \cdot 2 \times 10^{8} \\ 6 & 9 \cdot 2 \times 10^{8} \\ 8 & 8 \cdot 0 \times 10^{2} \\ 10 & 5 \cdot 2 \times 10^{2}\end{array}\right.$

At the end of the adsorption period, therefore, bound infective virus can be divided into three fractions. Fraction $A$ : between 52 and $93 \%$ of the total (mean $80 \%$ ) was susceptible to antiserum at the end of adsorption and lost its infectivity during the next $2 \mathrm{hr}$. of incubation at $37^{\circ}$ (Table 6). Fraction B: between 6.2 and $48 \%$ (mean $20.2 \%$ ), remained susceptible to antiserum for at least $6 \mathrm{hr}$. after adsorption, but did not lose an appreciable amount of its infectivity (Table 6). Fraction C: between 0.46 and $4.0 \%$ (mean $2 \cdot 4 \%$ ), which also retained most of its infectivity up to $6 \mathrm{hr}$. after adsorption, was insusceptible to antiserum throughout (Table 7). Part of this fraction probably corresponds to the 'EDTA fraction' of Stoker \& Ross (1958).

\section{Determination of fraction of virus involved in replication}

It was next necessary to decide which of the three fractions was responsible for the production of new virus. It was considered that if fraction $A$ were responsible then by the time it was inactivated ( $2 \mathrm{hr}$. after adsorption) some or all of it would have become insusceptible to antiserum. Incubation for $48 \mathrm{hr}$. of infected monolayers in the presence of antiserum added $2 \mathrm{hr}$. after adsorption should therefore, if the hypothesis were correct, give a greater yield of virus than incubation following addition of antiserum immediately after adsorption. Fraction $B$ was susceptible to antiserum throughout the first $6 \mathrm{hr}$. of incubation and would therefore not be involved in replication in the presence of antiserum. Fraction $\mathrm{C}$ showed very little decrease, and certainly no increase, in the $2 \mathrm{hr}$. after adsorption, so that if this were the fraction wholly responsible for production of new virus, the time of addition of antiserum should have no effect upon the size of the $48 \mathrm{hr}$. yield. If none 
of these three fractions were responsible for new virus, i.e. if new virus arose from virus which had entered the cells and lost infectivity during the adsorption period, then the time of addition of antiserum should have no effect on the $48 \mathrm{hr}$. yield.

The relationship of the $48 \mathrm{hr}$. yield to the amount of virus capable of replicating (fertile virus) was determined as follows. Monolayers were inoculated in the usual way with tenfold increasing dilutions of stock virus which were allowed to adsorb for $\mathbf{3 0} \mathrm{min}$. at $\mathbf{8 7 ^ { \circ }}$. After three washings with

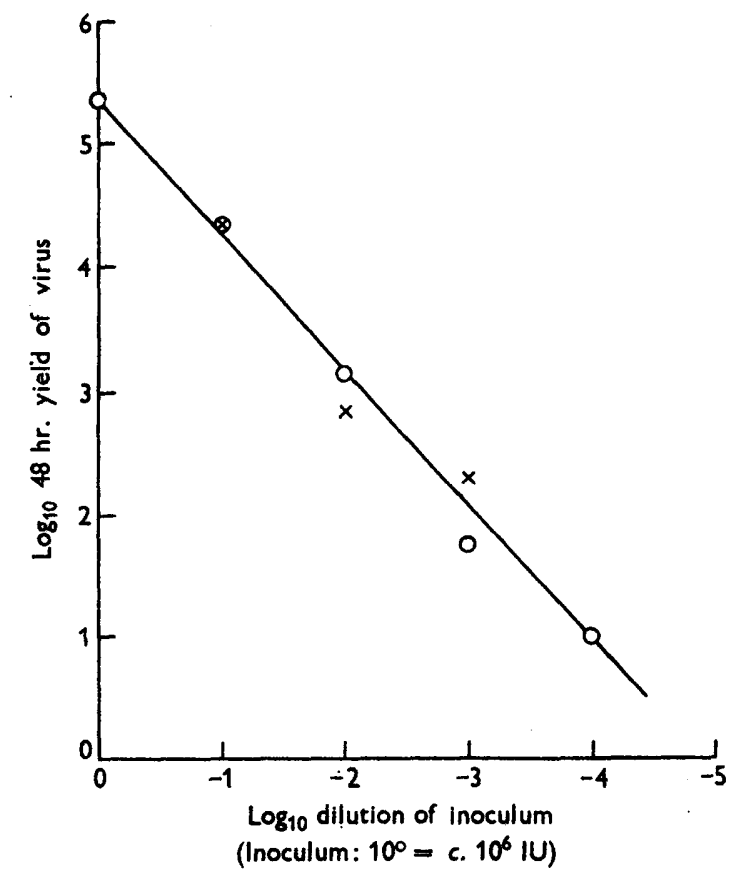

Fig. 1. Relationship between $48 \mathrm{hr}$. yield and size of inoculum of herpes simplex virus in HeLa cell monolayers ( 2 experiments).

$5 \mathrm{ml} .5 \%$ HSH the infected monolayers were covered with $5 \mathrm{ml}$. medium and incubated for $48 \mathrm{hr}$; ; after this they were again washed three times, disintegrated and titrated. Figure 1 shows a linear relationship (with slope $=1$ ) between $\log _{10}$ (yield) and $\log _{10}$ (dilution of inoculum) in two experiments. Experiments not reported here showed a linear regression of pock counts on the CAM against dilution of virus, so that the number of infective units in the inoculum was proportional to the dilution of the inoculum. Figure 2 shows the result of plotting $\log _{10}$ IU in inoculum against $\log _{10}$ IU adsorbed in $30 \mathrm{~min}$., using data from twelve determinations of these quantities in different experiments. All the points lie reasonably close to a straight line (whole slope =1) so that adsorbed IU was proportional to inoculated IU. For a multiplicity of infection of less than one the proportion of infective virus/cell complexes. which will be fertile may be assumed constant, if every cell-virus complex is

G. Microb. $\mathbf{x x n}$ 
independent and monolayers are produced under standard conditions. In these experiments the monolayers were made to contain more than $10^{6}$ cells, and the greatest amount of recoverable virus was $2.0 \times 10^{5}$, so that if adsorbed virus be assumed to be distributed among the cells according to the Poisson distribution, in the extreme case quoted less than $9 \%$ of the cells were infected with 2 or more IU. The proportion of virus/cell complexes containing 2 or more IU which will be fertile might be expected to be greater than the proportion in complexes containing one IU. If the latter proportion is $c$. $100 \%$ the small number of virus/cell complexes containing 2 or more IU makes very little difference to the validity of the assumption. Also, if fertility of the complex is determined by the cell only, the proportion of fertile complexes is independent of multiplicity, provided that one infectious unit does not interfere with another.

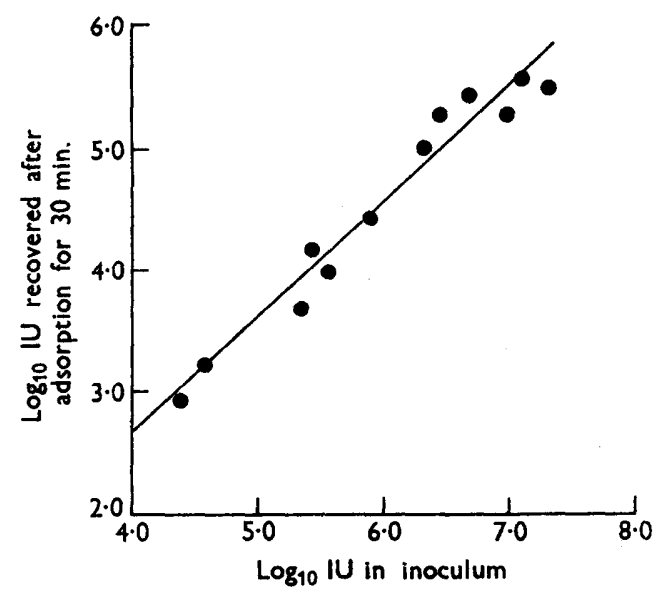

Fig. 2. Relationship between amount of herpes simplex virus adsorbed to HeLa cell monolayers in $80 \mathrm{~min}$. and amount of virus in the inoculum (data from 12 experiments).

Therefore: $48 \mathrm{hr}$. yield $=a \times$ virus in inoculum $=b \times$ adsorbed virus $=c$ $\times$ fertile virus $(a, b$, and $c$ being constants).

Therefore: fertile virus $=K \times 48 \mathrm{hr}$. yield, $K$ being a constant for the system.

Two kinds of experiment were designed to decide the issue. In both experiments monolayers were prepared, infected and washed as usual, after an adsorption period of $30 \mathrm{~min}$. One monolayer was disintegrated at once to provide a value for adsorbed recoverable virus and one was incubated for $48 \mathrm{hr}$. in $5 \mathrm{ml}$. medium to give the yield from cells not treated with antiserum. In the first type of experiment $5 \mathrm{ml}$. medium were placed on the remaining monolayers and $0.2 \mathrm{ml}$. volumes of undiluted antiserum were added at intervals after adsorption. The treated monolayers were then incubated without removing antiserum for $48 \mathrm{hr}$. at $37^{\circ}$; after this they were washed three times with $5 \mathrm{ml} .5 \% \mathrm{HSH}$, taken up in EDTA solution, disintegrated and titrated. The second type of experiment was performed in exactly the same way, except that the antiserum was removed after acting for $15 \mathrm{~min}$., 
the monolayers were washed three times, and $5 \mathrm{ml}$. fresh medium was added for incubation. The results are given in Table 9 in the form of the ratios $R_{1}$ ( $48 \mathrm{hr}$. yield in untreated monolayers : adsorbed virus) and $R_{\mathrm{a}}(48 \mathrm{hr}$. yield in monolayers treated with antiserum at various intervals : adsorbed virus), and the percentage $\left(R_{2} / R_{1}\right) \times 100$ (calculated only for the means of $R_{1}$ and $R_{2}$ ). The latter percentage, on the basis that yield is proportional to fertile virus, gives the percentage of total fertile virus which had become insusceptible to antiserum at various times. There are several interesting points. (a) In both types of experiment the value of $R_{2}$ at $2 \mathrm{hr}$. was much greater than at $0 \mathrm{~min}$. In one case it was 9 times as great, and in the other 8 times. (b) In the first type of experiment the $0 \mathrm{~min}$. value of $\left(R_{2} / R_{1} \times 100\right)$ was 0.8 , and although it increased during incubation it was only 25.5 after $6 \mathrm{hr}$.; thus it did not reach

\section{Table 9. Effect on yields when antiserum was added at intervals}

(a) Antiserum left on throughout $48 \mathrm{hr}$., then monolayers washed thoroughly and dirintegrated.

\begin{tabular}{|c|c|c|c|c|c|c|}
\hline \multirow[b]{2}{*}{ Expt. } & \multirow{2}{*}{$\begin{array}{l}\text { Adsorbed } \\
\text { (80 min. } \\
\text { adsorption) }\end{array}$} & \multirow{2}{*}{$\begin{array}{c}48 \mathrm{hr} \text {. yield } \div \\
\text { adsorbed } \\
\text { virus }\left(=\boldsymbol{R}_{1}\right)\end{array}$} & \multicolumn{4}{|c|}{$\begin{array}{l}48 \mathrm{hr} \text {. yield } \div \\
\text { adsorbed virus when } \\
\text { antiserum added at these } \\
\text { intervals after adsorption } \\
\left(=R_{\mathrm{g}}\right)\end{array}$} \\
\hline & & & 0 min. & $2 \mathrm{hr}$. & $4 \mathrm{hr}$. & $6 \mathrm{hr}$. \\
\hline \multirow{5}{*}{$\begin{array}{l}\text { H12 } \\
\text { H18 } \\
\text { H15 } \\
\text { H16 }\end{array}$} & $1.4 \times 10^{5 *}$ & 18 & $0 \cdot 1$ & $1 \cdot 0$ & - & - \\
\hline & $1.4 \times 10^{5 *}$ & $5 \cdot 5$ & 0.036 & 0.21 & 一 & - \\
\hline & $2.9 \times 10^{4}$ & 45 & 0.84 & $\mathbf{8 \cdot 8}$ & $\mathbf{3 \cdot 8}$ & $6 \cdot 0$ \\
\hline & $2 \cdot 0 \times 10^{5}$ & 25 & 0.26 & $1 \cdot 65$ & $1 \cdot 1$ & - \\
\hline & $\begin{array}{l}\text { Means } \\
\text { Mean } R_{2} /\end{array}$ & $23 \cdot 4$ & $\begin{array}{l}0.184 \\
0.8\end{array}$ & $\begin{array}{l}1.66 \\
7 \cdot 0\end{array}$ & $\begin{array}{r}2.5 \\
10.6\end{array}$ & $\begin{array}{r}6.0 \\
25 \cdot 5\end{array}$ \\
\hline
\end{tabular}

(b) Antiserum removed after $15 \mathrm{~min}$. Monolayers washed $\times 3.5 \mathrm{ml}$. of fresh medium added.

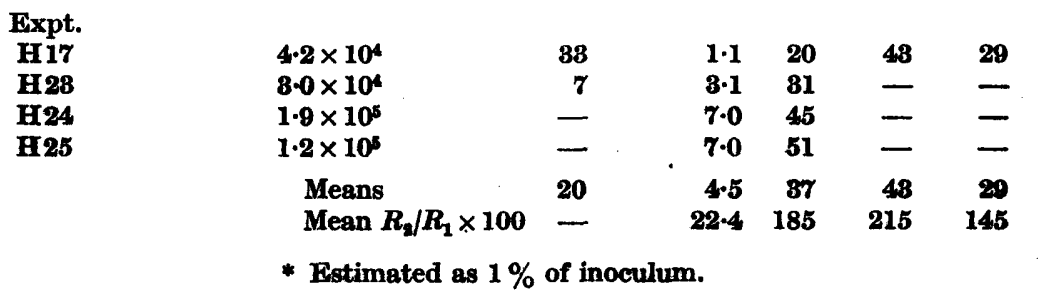

the theoretical maximum value of 100 . On the other hand, in the second type of experiment, in which antiserum was removed, the 0 min. value was $22 \cdot 4$ and the maximum value had been reached by $2 \mathrm{hr}$. Both results support the hypothesis that fraction $A$ was giving rise to new virus, and therefore that eclipse of infectivity was a part of the growth cycle of herpes virus, since both results showed that the amount of fertile virus insusceptible to antiserum increased during the first $2 \mathrm{hr}$. The second set of results shows that all the fertile virus had escaped in $2 \mathrm{hr}$. The possible reasons for the differences between the two results will be discussed later. (c) The second type of experiment probably gives a truer picture of events than the first. In this case the 
mean $\left(R_{2} / R_{1}\right) \times 100$ value at 0 min. was $22 \cdot 4$, which indicates that about $22.4 \%$ of adsorbed fertile virus had become insusceptible to antiserum at the end of adsorption. Fraction C consisted of only 0.4-4.0\% of adsorbed infective virus, and fraction $B$ was always susceptible to antiserum. Fraction $\mathbf{A}$ was wholly susceptible to antiserum at the end of adsorption. There must therefore have been a fourth fraction, fraction $D$, consisting of virus which had lost its infectivity and had become insusceptible to antiserum during the adsorption period.

By taking the mean values of all the fractions the distribution of all detectable adsorbed virus after $80 \mathrm{~min}$. adsorption can be estimated. Stoker \& Ross (1958; Table 1) gave an estimate of the distribution of herpes virus associated with HeLa cells, taking the amount which had disappeared from the inoculum as $100 \% ; 22 \%$ of this was removed by washing the cells three times. When this amount is left out of the reckoning, since monolayers in the above experiments were washed three times, their figures can be rearranged for comparison with the distribution of fractions A to D (Table 10); fractions which presumably correspond are set out adjacently. The values are quite close, especially when it is considered that the adsorption period in the experiment of Stoker \& Ross was one hour. Since their studies were made on infected HeLa cells treated with antiserum it seems probable that growth in their cells occurred from fraction D, which corroborates the conclusions they reached concerning the eclipse of herpes virus.

Table 10. Distribution of fractions ( $\%$ of adsorbed virus)

Stoker \& Ross's (1968) data (
Removed in sth to oth wash
Thermal inactivation ete.
FDTA fraction
Disintegrated cells
Deficit

Stoker

Thermal inactivation etc.

Deflcit
Data from present experiments

$8 \%$
$8 \%$
$5 \%$
$48 \%$
$41 \%$

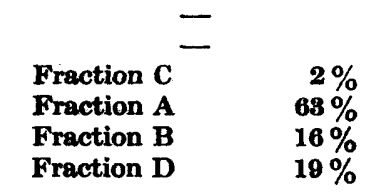

(d) The most immediate explanation for the different results in the two types of experiment (see (b), above) was that incubation for $48 \mathrm{hr}$. in the presence of antiserum prevented secondary infection of cells by virus released into the medium during the first and subsequent growth cycles. Table 11 gives the results of some experiments which suggest that this may not be the correct explanation. Infected monolayers were incubated for $48 \mathrm{hr}$, in medium at $7^{\circ}$; free virus in the medium (after gentle agitation of the bottle twenty times) was then titrated at the same time as virus recovered from washed disintegrated cells. In two other experiments, two monolayers were infected, washed, and incubated at $37^{\circ}$ for $48 \mathrm{hr}$. One monolayer was washed twice and its virus content assayed. To the other monolayer, after washing twice, $2 \mathrm{ml}$. 1/50 antiserum were added. After $15 \mathrm{~min}$. contact with antiserum at $87^{\circ}$ this monolayer was again washed three times and its virus content assayed. The results show that an insignificant proportion of the yield of virus was in the medium at $48 \mathrm{hr}$., in spite of the fact (Table 6, control) that the virus was quite stable in growth medium for $8 \mathrm{hr}$. at $87^{\circ}$. Furthermore, the bulk of the 
yield virus not removed by two washings was insusceptible to antiserum. The fact that the medium contained little virus, even after agitating the culture bottles, is evidence against the presence on the monolayers of significant amounts of antiserum-susceptible yield virus in such a state that its attachment could not resist two - washings, which were no more vigorous than the agitation. These results suggest that very little secondary infection occurred through the medium. Furthermore, Farnham (1958) and others have shown that plaques may develop in HeLa cells in the presence of antiserum, although the plaques are somewhat smaller. Possibly cells bathed in antiserum produce virus at a decreased rate. Ishida \& Ackermann (1956), referring to unpublished results, claimed that immune serum could inhibit the late stages of influenza virus development; phenomena suggesting this possibility may have occurred in these experiments.

\begin{tabular}{|c|c|c|c|c|}
\hline IU adsorbed/monolayer & $2.1 \times 10^{8}$ & - & $1.4 \times 10^{5 *}$ & $1.4 \times 10^{04}$ \\
\hline $\begin{array}{l}\text { IU recovered from } \\
\text { washed, disintegrated } \\
\text { cells after } 48 \mathrm{hr} \text {. at } 87^{\circ}\end{array}$ & $5.0 \times 10^{6}$ & $2 \cdot 8 \times 10^{4}$ & $1.9 \times 10^{8}$ & $6.4 \times 10^{5}$ \\
\hline $\begin{array}{l}\text { IU recovered from } \\
\text { washed, disintegrated } \\
\text { antiserum-treated cells } \\
\text { after } 48 \mathrm{hr} \text {, at } 37^{\circ}\end{array}$ & - & - & $2.5 \times 10^{8}$ & $7 \cdot 6 \times 10^{5}$ \\
\hline $\begin{array}{l}\text { IU recovered from } \\
\text { medium after } 48 \mathrm{hr} \text {. at } \\
\mathbf{8 7 ^ { \circ }}\end{array}$ & $1.5 \times 10^{4}$ & $8.0 \times 10^{2}$ & - & - \\
\hline
\end{tabular}

The relationship of escape from antiserum to inactivation

Fraction $\mathrm{C}$ did not increase during the $2 \mathrm{hr}$. after adsorption when fertile virus was becoming insusceptible to antiserum (Table 7, Expts. 71 and 78), but showed, if anything, a decrease. There is therefore no evidence that virus was accumulating in a serum-insusceptible state before it lost its infectivity. That is to say, inactivation of fraction $A$ occurred either at the same rate, or at a more rapid rate, than development of insusceptibility to antiserum. If the second possibility were correct the situation would be analogous to that in CAM ectoderm infected with herpes virus, where virus lost its infectivity before becoming insusceptible.

A measure of the rate of development of insusceptibility was obtained from the rate of increase of $48 \mathrm{hr}$. yield when antiserum was added to infected monolayers at increasing intervals after adsorption. This was compared with the rate of inactivation in two experiments. Ten monolayers were infected as usual by adsorption for $\mathbf{3 0} \mathrm{min}$. After three washings fresh medium was placed on the cells which were incubated at $37^{\circ}$. One monolayer was disintegrated and assayed every $80 \mathrm{~min}$. during $2 \mathrm{hr}$., starting at $0 \mathrm{~min}$. after adsorption. At the same intervals other monolayers were treated by addition of $0.2 \mathrm{ml}$. 
antiserum to the medium. The antiserum was allowed to act for $15 \mathrm{~min}$., after which the monolayers were washed three times and covered with $5 \mathrm{ml}$. fresh medium. The yields from these monolayers were measured after $48 \mathrm{hr}$. at $87^{\circ}$. The results (Table 12) are expressed, for the inactivation rate, as the factor 'virus recovered at given interval/virus recovered at 0 min.' and for the rate of development of insusceptibility, as 'virus yield with antiserum added at given interval/yield with antiserum added at 0 min.' Too few experiments were done for an accurate statement of the rates to be given, but the results show that inactivation and insusceptibility developed gradually over the period from $80 \mathrm{~min}$. to $2 \mathrm{hr}$. after adsorption. There is nothing in the values to suggest that inactivation occurred much more rapidly than the development of insusceptibility. The values also suggest that for about the first $\mathbf{3 0} \mathrm{min}$. virus was neither becoming inactivated nor insusceptible to antiserum. The figures support the hypothesis that adsorbed virus remained on the cells for a period without undergoing any change of state, and that inactivation and insusceptibility to antiserum developed very closely together in time, possibly simultaneously.

Table 12. Relationship of inactivation of adsorbed virus to development of
serum-insusceptibility
Interval between end of adsorption and
disintegration or addition of antiserum
(min.)

\section{DISCUSSION}

The picture of herpes virus infection of HeLa cells presented above differs in many respects from that of infection in CAM ectoderm. In the latter cells loss of infectivity occurred very soon after, and possibly simultaneously with, firm binding to the cells; in HeLa cells it took place gradually over a period of c. 2 hr. Fertile virus became insusceptible to antiserum in CAM cells within $3 \mathrm{hr}$. of inactivation; in HeLa cells the two processes probably occurred very elosely together in time. The $48 \mathrm{hr}$. yield of virus, expressed as a multiple of the amount of virus adsorbed, was about 20 in HeLa cells and of the order of $10^{8}$ in CAM cells. In spite of these differences, however, the fundamental pat- 
tern of virus replication was the same, in that new virus developed from the fractions which had lost their infectivity at or near the surface of the cells.

In studies on influenza virus infection of chorio-allantoic membrane Ackermann, Ishida \& Maassab (1955) and Ishida \& Ackermann (1956) found evidence that the adsorbed virus existed as 'Bound Infectious Virus' (BIV), and 'Initiating activity' (IA). BIV probably corresponds to fractions B and C in my experiments, and IA to fractions $A$ and $D$. These workers also found that the initial cell-virus complex formed at $4^{\circ}$ became non-infective but was still sensitive to immune serum; at $37^{\circ}$ the complex became steadily insusceptible. These findings are very similar to those reported here for herpes virus in that this virus formed a stable complex with the cell at $37^{\circ}$ and then became insusceptible to antiserum as it lost its infectivity.

The experiments in HeLa cells and CAM show that, after adsorption of herpes virus, viral antigens can combine with antibody and prevent infection. Two points require further examination. First, does union of attached virus with antibody prevent entry into the cell, or does the antibody prevent some intracellular reaction leading to replication? Secondly, are the chemical groupings on the virus surface which are presumably responsible for firm binding identical with the antigens which combine with antibody after adsorption to produce neutralization? If they are not identical, but are antigenic, would their combination with the appropriate antibody lead to neutralization? In other words, does 'neutralizing antiserum' contain more than one kind of neutralizing antibody?

\section{REFERENCES}

Ackrrmann, W. W., Ishida, N. \& Maassab, H. F. (1955). Growth characteristics of influenza virus concerning the binding of virus by host cells. J. exp. Med. $102,545$.

Bedson, S. P. \& Gosturng, J. V. T. (1958). Further observations on the mode of multiplication of herpes virus. Brit. J. exp. Path. 39, 502.

Farnham, A. E. (1958). The formation of microscopic plaques by herpes simplex virus in HeLa cells. Virology, $6,817$.

Ismod, N. \& AckermanN, W. W. (1956). Growth characteristics of influenza virus. Properties of the initial cell-virus complex. J. exp. Med. 104, 501.

Stoker, M. G. P. \& Ross, R. W. (1958). Quantitative studies on the growth of herpes virus in HeLa cells. J. gen. Microbiol. 19, 250.

WatKriss, J. F. (1960). The adsorption, penetration and eclipse of herpes simplex virus in chorio-allantoic membrane ectoderm. J. gen. Microbiol. 22, 40.

Windy, P., Stoker, M. G. P. \& Ross, R. W. (1959). Release of herpes virus from solitary HeLa cells. J. gen. Microbiol. 20, 105. 